\title{
Kemp's ridley Lepidochelys kempii nesting abundance in Texas, USA: a novel approach using genetics to improve population census
}

\author{
Amy Frey ${ }^{1, *}$, Peter H. Dutton ${ }^{1}$, Donna J. Shaver ${ }^{2}$, Jennifer Shelby Walker $^{2}$, \\ Cynthia Rubio²
}

${ }^{1}$ Marine Mammal and Turtle Division, Southwest Fisheries Science Center, National Marine Fisheries Service, National Oceanic and Atmospheric Administration, 8901 La Jolla Shores Dr., La Jolla, California 92037, USA

${ }^{2}$ Division of Sea Turtle Science and Recovery, Padre Island National Seashore, National Park Service, PO Box 181300 , Corpus Christi, Texas 78480-1300, USA

\begin{abstract}
Accurate estimates of the annual numbers of nesting females are critical for assessing sea turtle populations. Nesting by Kemp's ridley Lepidochelys kempii turtles has significantly increased at Padre Island National Seashore and nearby beaches in Texas, USA. Four nests were observed in Texas during 1995 and a record of 209 in 2012. However, it is unclear how many clutches are laid by the same females. We used a genetic approach to infer the number of individual nesters from genotypes determined from dead embryos and hatchlings sampled from clutches. Mitochondrial DNA sequencing was combined with nuclear DNA analysis at 10 microsatellite loci to match genotypes for nesters and offspring of unknown parentage in over $50 \%$ of the unassigned nests. Our results indicate that traditional methods, based on observed tagged turtles, have underestimated the number of Kemp's ridleys nesting in Texas. We demonstrate how genetic approaches can be incorporated into population assessments when direct census of adult animals is not feasible. This approach also provides a basis to apply capture-mark-recapture techniques to assess the impact of events, such as the recent oil spill, on the population via sampling of nests to identify and track individual nesters over time.
\end{abstract}

KEY WORDS: Kemp's ridley $\cdot$ Sea turtle $\cdot$ Abundance $\cdot$ Nesting beach $\cdot$ Genotypes Resale or republication not permitted without written consent of the publisher

\section{INTRODUCTION}

Sea turtle populations are most commonly surveyed at nesting beaches. This provides estimates of the numbers of females nesting annually from direct observation and tagging for capture-mark-recapture (CMR) studies (Chaloupka \& Limpus 2001, Kendall \& Bjorkland 2001, Balazs \& Chaloupka 2006) or by counting turtle tracks left on beaches (Witherington et al. 2009, Tucker 2010). Since most sea turtles do not nest annually, accurate estimates of population size rely upon long-term monitoring of females at their nesting beaches (Dutton et al. 2005, Troëng \&
Rankin 2005, Allen et al. 2010). Nesting female abundance has been estimated by dividing total annual nest counts by the average number of clutches laid per female in a season (Allen et al. 2010). Nesting parameters, such as re-migration interval and annual female nest production, are challenging to obtain and are essential for estimating the size of nesting sea turtle populations (Richards et al. 2011).

Ridley turtles Lepidochelys spp. are unlike other sea turtles because they typically nest in arribadas, where the females haul out en masse to lay their eggs generally at the same time. Special approaches have been designed to quantify nesting in the case 
of olive ridleys L. olivacea (Kumar et al. 2013). Kemp's ridley L. kempii, whose geographical range is limited to the Gulf of Mexico and the Atlantic Ocean, is considered Critically Endangered by the IUCN (Fontaine \& Shaver 2005). Most nesting occurs on beaches of Tamaulipas and Veracruz in Mexico, where the number of nesting females plummeted from an estimated 40000 on one day in the 1940s to approximately 250 females nesting in 1985 (NMFS et al. 2011). In the late 1970s, the US and Mexican governments initiated a bi-national project as part of a broad effort to save this species from extinction (Dutton et al. 2002). The goal of the project was to form a second nesting colony of this native species at Padre Island National Seashore (PAIS), Texas, which is the longest stretch of undeveloped barrier island in the world and the northern extent of the documented historic nesting range of the species (Shaver 2005).

Monitoring for nesting began on the Texas coast at PAIS in 1986 but was sporadic until the late 1990s, when monitoring efforts also began expanding to other Texas Gulf beaches (Shaver 2005). Kemp's ridley nesting has increased throughout the species' range in recent years (NMFS et al. 2011, Shaver \& Caillouet in press). Although Kemp's ridley nesting in Texas is now state-wide, it continues to be concentrated in the documented historic nesting range, with more than half the Kemp's ridley nests recorded in the USA annually located at PAIS.

Accurate estimates of the number of females nesting in Texas are essential for the conservation and management of the Kemp's ridley and for evaluation of results from the effort to form a secondary nesting colony of the species at PAIS. However, with such a large stretch of beach $(591 \mathrm{~km})$ and a small nesting population, monitoring the nesting turtles is logistically challenging and the probability of encountering a nesting female is low. Even though the beach is monitored, and the females that are encountered are tagged and sampled, approximately $50 \%$ of the nests are found only after the female has departed, leaving the identity of the individual nester unknown (Shaver 2005, Shaver \& Caillouet in press). Since each female can lay multiple clutches in a season and in different years, and these basic nesting parameters are not known for Texas, it has not been possible to derive meaningful population size estimates for Kemp's ridleys nesting in Texas from nest counts alone. Furthermore, since the probability of encountering the females during nesting is relatively low, CMR analysis of the limited tagging data is problematic (Kendall 2004).
In recent years, molecular parentage based studies have been used for population assessments and for determining demographic parameters (Stewart \& Dutton 2011, Wright et al. 2012, Frey et al. 2013). Genetic markers may be used to clarify relationships among individuals and to establish reliable pedigrees, which can be useful for estimating population size (Blouin 2003, Herbinger et al. 2006). Genetic identification of female nesters provides a tool for CMR studies; when the identity of the nesting female is unknown for a nest, genetic approaches can be used to determine whether any sampled females can be matched to that nest.

The purpose of this study was to develop and apply genetic approaches to estimate the abundance of Kemp's ridley females nesting annually in Texas. Using genetic profiles constructed from microsatellite genotypes and mtDNA sequences of observed nesters as well as dead embryos and hatchlings salvaged from nests, we were able to establish the identity of the mothers of the unknown nests and derive new counts for the number of nesting females. This is a useful tool for estimating abundance when direct census data are limited, and it provides the basis for improving CMR studies to address basic population parameters (such as nesting ecology, mating systems, and remigration intervals).

\section{MATERIALS AND METHODS}

\section{Sample collection}

Surveys are conducted annually along the entire Texas Gulf of Mexico beachfront between April and mid- July, which marks the annual nesting season for the Kemp's ridley in Texas. When nesting turtles are encountered they are examined and tagged with metal tags in the front and rear flippers and a passive integrated transponder (PIT) tag in the front flipper, in order to identify the individual when she returns to the beach. Additionally, a blood or tissue sample is collected unless that female has already been sampled. During the 2001 to 2008 nesting seasons, blood or tissue samples were collected from 159 females following the protocols described by NMFS Southeast Fisheries Science Center (2008). Eggs from virtually all nests found are relocated to hatcheries (Shaver 2005, Shaver \& Caillouet in press). After fullterm clutch incubation, residual nest contents are examined to quantify hatching and emergence success, determine embryological stage of development at time of death, and collect tissue samples from dead 
hatchlings and embryos (Shaver 2005). During the 2003 to 2006 nesting seasons, tissue samples were collected from dead embryos or hatchlings from 141 nests. The study site and nest locations are shown in Fig. 1. Blood and tissue samples were frozen or preserved in DMSO salt solution and shipped to the NOAA Southwest Fisheries Science Center for longterm storage and analysis.

\section{Laboratory analysis}

We extracted genomic DNA from 159 nesting female samples, collected between 2001 and 2008, and a total of 510 salvaged embryos and hatchlings collected from 141 nests excavated during the 2003 through 2006 nesting seasons, using the highthroughput X-tractor Gene extraction robot (Corbett Robotics). For 36 of the nests, the nesting female was identified and sampled in the field, for 15 of the nests the female was identified in the field, but no sample was collected, and for the remaining 90 nests, the mother was unknown. We genotyped each sample at 10 microsatellite loci: Cc1H11,
Cc5C8, Cc5H7, Cc7E11 (Shamblin et al. 2008), Cm3 (FitzSimmons et al. 1995), D1, D2, D108 (Dutton \& Frey 2009), Or2, and Or7 (Aggarwal et al. 2004) (Table 1). We used the PCR conditions described by Dutton \& Frey (2009) and optimized annealing temperature for each primer pair. PCR products were labeled using standard sequencing dyes (HEX or FAM; Applied Biosystems). Amplification of the PCR product was verified using a $2 \%$ agarose gel with ethidium bromide stain (Maniatis et al. 1982). Products were then separated on an ABI 3100 or 3730 DNA analyzer with Genescan Rox500 fluorescent size standard (PE Applied Biosystems). Additionally, we amplified and sequenced the mtDNA control region using the primers H950g and LCM15382 (Abreu-Grobois et al. 2006) under PCR conditions described by LeRoux et al. (2012) for at least 1 sample from each of the 141 nests and all of the nesting females. MtDNA sequences were aligned and assigned haplotypes using Seqscape v2.5 (PE Applied Biosystems). Microsatellite data were scored using GeneMapper v4.0 (PE Applied Biosystems), and each allele call was verified manually.

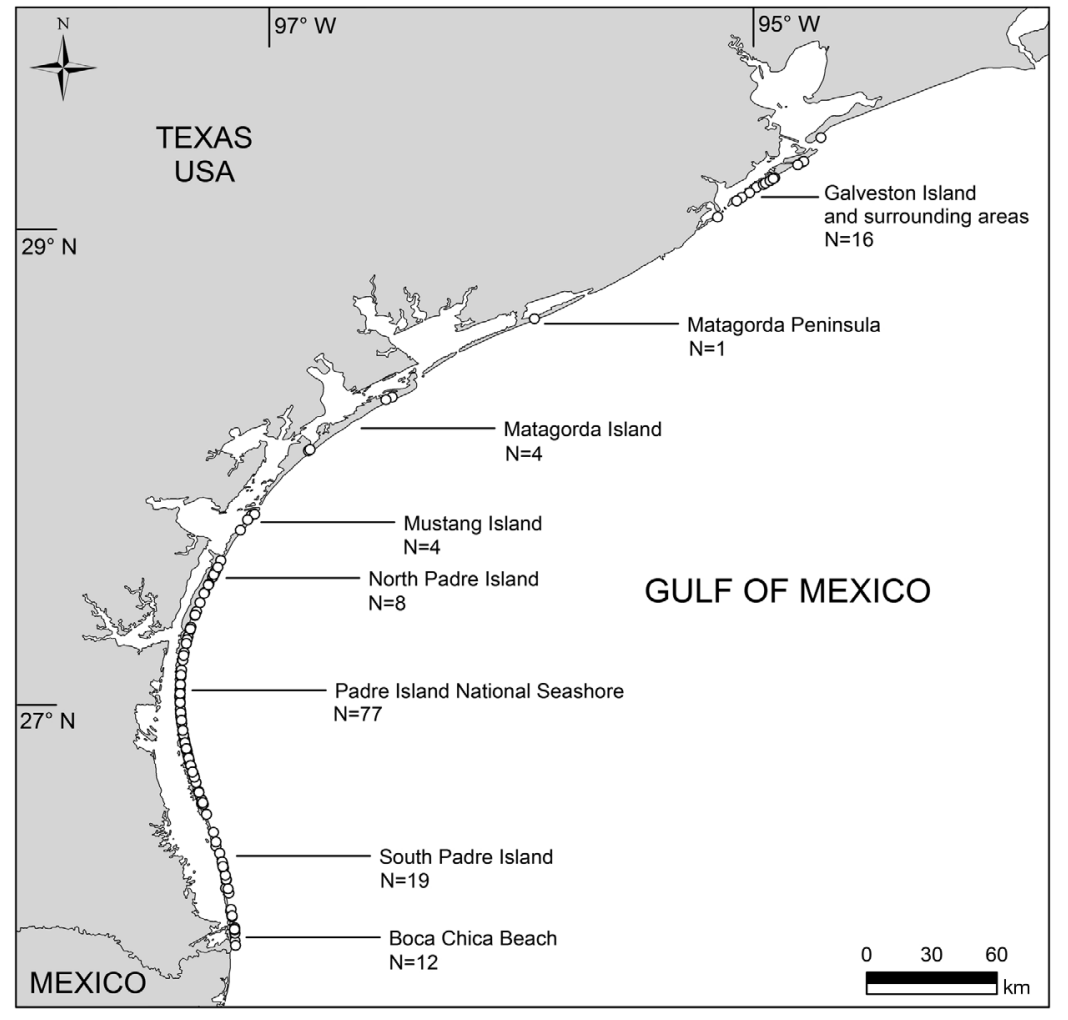

Fig. 1. Study site and nest locations of hatchling samples (of Kemp's ridley turtles Lepidochelys kempii collected between 2003 and 2006 at Padre Island National Seashore and nearby beaches in Texas, USA. N: number of nests sampled at that location

\section{Statistical analysis}

We tested all 10 microsatellite markers for Mendelian inheritance using hatchlings from nests where the female was observed and sampled while nesting. Using the nesting female dataset, each marker was tested for allelic stutter, null alleles, and large allele dropout using MicroChecker (Van Oosterhout et al. 2004), Hardy-Weinberg equilibria (HWE) were tested using the nesting female dataset using GENEPOP (Raymond \& Rousset 1995), and the probability of identity and the probability of exclusion were calculated using GenAlEx (Peakall \& Smouse 2012). To estimate our genotyping error rate, we randomly selected and replicated $10 \%$ of our sample set.

To identify which female was responsible for each of the nests, we used 2 software programs, Cervus v3.0 (Kalinowski et al. 2007) and Colony v2.0 (Jones \& Wang 2010). We treated all of the 141 nests as unknown nests 
Table 1. Lepidochelys kempii. Summary statistics for the 10 loci used to genotype hatchlings and females: number of individuals $(\mathrm{N})$, number of alleles $(k)$, expected heterozygosity $\left(H_{\mathrm{e}}\right)$, observed heterozygosity $\left(H_{\mathrm{o}}\right)$, Hardy-Weinberg $\mathrm{p}$ value $\left(\mathrm{p}_{\mathrm{HW}}\right)$, error rate, probability of identity $\left(\mathrm{p}_{\mathrm{ID}}\right)$, and probability of exclusion $\left(\mathrm{p}_{\mathrm{ex}}\right)$

\begin{tabular}{|lcccccccc|}
\hline Locus & $\mathrm{N}$ & $k$ & $H_{\mathrm{e}}$ & $H_{\mathrm{o}}$ & $\mathrm{p}_{\mathrm{HW}}$ & Error rate & $\mathrm{p}_{\mathrm{ID}}$ & $\mathrm{p}_{\mathrm{ex}}$ \\
\hline Cc1H11 & 159 & 20 & 0.914 & 0.899 & 0.603 & 0.015 & 0.015 & 0.70 \\
Cc5C8 & 160 & 19 & 0.921 & 0.919 & 0.428 & 0.034 & 0.013 & 0.72 \\
Cc5H7 & 160 & 18 & 0.917 & 0.925 & 0.955 & 0.017 & 0.014 & 0.70 \\
Cc7E11 & 157 & 17 & 0.883 & 0.873 & 0.136 & 0.025 & 0.026 & 0.61 \\
Cm3 & 157 & 12 & 0.791 & 0.745 & 0.512 & 0.040 & 0.072 & 0.42 \\
D1t & 158 & 16 & 0.883 & 0.867 & 0.252 & 0.065 & 0.013 & 0.71 \\
D2t & 160 & 15 & 0.895 & 0.900 & 0.150 & 0.037 & 0.025 & 0.62 \\
D108 & 159 & 19 & 0.918 & 0.893 & 0.480 & 0.032 & 0.021 & 0.64 \\
Or2 & 161 & 10 & 0.722 & 0.820 & 0.903 & 0.024 & 0.110 & 0.33 \\
Or7t & 160 & 4 & 0.531 & 0.550 & 0.574 & 0.031 & 0.272 & 0.14 \\
\hline
\end{tabular}

for the purpose of ground-truthing both our markers and the analysis software. Cervus uses a likelihoodbased method to assign parentage, allowing for genotyping errors. The software runs a simulation of the data to assess the power of the given markers as well as the confidence of the parentage assignments. The input data for the simulation included allele frequencies from the nesting female population, 10000 offspring, 2000 candidate mothers, and 0.75 for the proportion of candidate females sampled. Our proportion of loci genotyped was 0.98 , with 0.01 mistyped and a minimum of 6 loci typed. Using allele frequencies generated from our potential parent genotypes, in combination with the simulation file, the likelihood of parentage for each candidate parent was calculated.

Colony is used to determine full- and half-sibling relationships. It allows sibship reconstruction even without parental information. We allowed for both male and female polygamy and inbreeding as input parameters (Lee 2008) and chose the full likelihood model with medium precision. A description of the method and its performance may be found in Wang \& Santure (2009). Allele frequencies were calculated by Colony using the hatchling data. Allele frequency estimates were updated by Colony while searching for the maximum-likelihood configuration based on the inferred sibship and parentage relationships. The sibship size prior was left blank. Each of the 10 markers was considered codominant with the allelic dropout rate being 0 ; the error rate we used was calculated during the genotyping replication exercise (Table 1). In the analysis, there were 510 offspring genotypes, 0 candidate male genotypes, and 159 candidate female genotypes. Any samples known to be from the same nest were coded as known maternal siblings. Certain conditions required that some females be excluded as potential mothers responsible for some of the hatchling sets. For example, if a hatchling set had a different maternally inherited mtDNA haplotype than a candidate mother we assumed that she was not the mother of the hatchling and excluded her as a potential parent. We used the relationships assigned in Colony to group the nests into known-mother sets and then compared the relationships manually. Putative maternal genotypes were assigned by Colony, along with the probability that the genotype for each marker was correct, for each hatchling set where a match was not found.

\section{RESULTS}

Each of the 10 loci was in HWE, and the average number of alleles per locus ranged from 4 to 20, with an average of 15 . The expected heteroyzgosity ranged from 0.531 to 0.921 , with an average of 0.838 . The probability of identity for all 10 loci was $1.0 \times 10^{-15}$, the probability of exclusion for each locus ranged from 0.14 to 0.72 with an average of 0.56 , and the overall probability of exclusion was 1.00 . The mean genotyping error rate was $0.032 \%$ (range: 0.015-0.065).

We identified 8 new mtDNA haplotypes (Table A1 in the Appendix) represented by the nesting females. The 2 most common haplotypes, Lk4.1 and Lk6.1, represent $82 \%$ of the nesting females. For the nests with a rare haplotype $(n=10)$, the pool of potential mothers is reduced from 163 to 30 females.

\section{Ground truthing (known nests)}

Of the 36 analyzed nests in which the female was observed and sampled while nesting, 75 samples were used to ground-truth each of our loci and our analysis methods. Of the nest assignments made by Colony, $89 \%$ (32 out of 36) were correct (Table 2). The software was unable to match 2 of the nests to the sampled female that was observed while nesting, and the software incorrectly assigned 2 nests to the wrong female. Cervus correctly assigned $78 \%$ (28 out of 36) of the nests, with $95 \%$ confidence for at least half of the hatchlings from the nest (with the 
Table 2. Lepidochelys kempii. Parentage assignment results of independent analysis for nests where the mother was observed in the field while nesting. To identify which female was responsible for each of the nests, the software programs Cervus and Colony were used; see 'Materials and methods' for details

\begin{tabular}{|ccccc|}
\hline Year & No. nests & $\begin{array}{c}\text { No. nests } \\
\text { assigned } \\
\text { (Cervus) }\end{array}$ & $\begin{array}{c}\text { No. nests } \\
\text { assigned } \\
\text { (Colony) }\end{array}$ & $\begin{array}{c}\text { No. nests } \\
\text { not } \\
\text { assigned }\end{array}$ \\
\hline 2003 & 3 & 2 & 3 & 0 \\
2004 & 15 & 11 & 11 & 2 \\
2005 & 14 & 14 & 14 & 0 \\
2006 & 4 & 3 & 4 & 0 \\
Total & 36 & 30 & 32 & 2 \\
\hline
\end{tabular}

remaining hatchlings assigned to the same female with varying confidence). For the remaining 8 nests, there were 2 nests in which the correct assignments were made with $80 \%$ confidence. Two nests were assigned correctly with $95 \%$ confidence for half of the hatchlings, but the other half assigned incorrectly to a different female. One nest was assigned to the correct female as the most likely parent without confidence for 2 hatchlings and could not be assigned for the other 2 hatchlings; 1 nest was assigned incorrectly; and 2 nests were not assigned to any female.

\section{Unknown nests}

We evaluated 90 nests for which the mother was unknown (Table 3). Cervus and Colony each correctly assigned $50 \%$ of the nests to a sampled female. Of the remaining 44 nests, 25 were assigned to 19 additional females for which putative genotypes were also assigned by Colony. The genotypic fingerprints were generated for those 19 females, along with a probability that each genotype for each
Table 3. Lepidochelys kempii. Parentage assignment results of independent analysis for nests where the mother was initially unknown, but subsequently derived from the pool of sampled females. To identify which female was responsible for each of the nests, the software programs Cervus and Colony were used; see 'Materials and methods' for details

\begin{tabular}{|ccccc|}
\hline Year & No. nests & $\begin{array}{c}\text { No. nests } \\
\text { assigned } \\
\text { (Cervus) }\end{array}$ & $\begin{array}{c}\text { No. nests } \\
\text { assigned } \\
\text { (Colony) }\end{array}$ & $\begin{array}{c}\text { No. nests } \\
\text { not } \\
\text { assigned }\end{array}$ \\
\hline 2003 & 7 & 1 & 2 & 5 \\
2004 & 16 & 7 & 7 & 9 \\
2005 & 19 & 8 & 8 & 11 \\
2006 & 48 & 29 & 28 & 20 \\
Total & 90 & 45 & 45 & 44 \\
\hline
\end{tabular}

marker was correct. These 25 nests and 19 putative females were grouped together and the genotypes were examined visually. The remaining 19 nests were assigned by Colony to turtles in the candidate female pool, but were determined to be incorrect after comparing the genotypes visually.

Combining the field observations and tag data along with genotype matching, the number of females nesting annually ranged from 11 in 2003 to 51 in 2006, and a total of 101 different females nested between 2003 and 2006 (Table 4). The average number of nests laid per female in a year was 1.27 nests in 2003, 1.37 in 2004, 1.39 in 2005, and 1.78 nests in 2006 , based on the total number of sampled nests assigned (Table 4). Between 2003 and 2006, an average of $23.2 \%$ of the females were re-migrants. Of the females that nested in 2003, 1 re-migrated in 2005 and 1 in 2006. Of the 2004 nesters, 2 females remigrated in 2005, and 9 in 2006. Of the females that nested in 2005, 3 re-migrated in 2006. Five females returned to nest in consecutive years; 2 of them were observed in the field in both years, and 3 were identified using genetics.

Table 4. Lepidochelys kempii. Number of females nesting annually in Texas determined using genetic analysis methods. Shown are the number of females and nests observed in the field, number of females and nests assigned using genetics, number of females observed in the field and assigned using genetics, total number of females assigned and number of nests assigned, total number of nests observed for the season, and estimated number of females based on nest counts and previously published values of 2.5 (range 1.8-3.1) clutches laid per season (NMFS et al. 2011)

\begin{tabular}{|ccccccc|}
\hline Year & $\begin{array}{c}\text { Females observed } \\
\text { (nests) }\end{array}$ & $\begin{array}{c}\text { Females assigned } \\
\text { using genetics } \\
\text { (nests) }\end{array}$ & $\begin{array}{c}\text { Females observed } \\
\text { assigned using } \\
\text { genetics }\end{array}$ & $\begin{array}{c}\text { Total females } \\
\text { (nests assigned) }\end{array}$ & $\begin{array}{c}\text { Total observed } \\
\text { nests }\end{array}$ & $\begin{array}{c}\text { Estimated no. } \\
\text { females (range) }\end{array}$ \\
\hline 2003 & $8(10)$ & $6(7)$ & 3 & $11(14)$ & 19 & $7.6(6.2-10.6)$ \\
2004 & $19(23)$ & $12(16)$ & 4 & $27(37)$ & 42 & $16.8(13.9-23.3)$ \\
2005 & $20(25)$ & $13(19)$ & 5 & $28(39)$ & 50 & $20.0(16.3-27.8)$ \\
2006 & $43(50)$ & $28(48)$ & 20 & $51(91)$ & 102 & $40.8(33.2-56.7)$ \\
\hline
\end{tabular}




\section{DISCUSSION}

This study demonstrates the value of genetic tools for matching offspring to females, especially for endangered wildlife species. Other studies have used similar approaches for wildlife population studies (e.g. polar bears, Cronin et al. 2009; eastern imperial eagles, Rudnick et al. 2007). Our study presents a novel approach to census nesting marine turtles using genetics to associate females to nests and provides an alternative method for identifying nests laid by unknown mothers, especially in areas where direct observation of nesting females is not possible. Current census methods rely on counting the nesting females, which is labor intensive and often not feasible, or counting crawls or nests. In the latter case, site-specific data on average clutches per female from CMR data are needed (Schroeder \& Murphy 1999).

\section{Ground truthing}

Evaluating 36 nests with known, sampled mothers allowed us to ground truth both our markers and our methods. We chose 10 highly polymorphic (mean $H_{\mathrm{o}}$ $=0.839$ ) microsatellite loci, which are the best markers for parentage analysis (Sefc \& Koblmüller 2009), in combination with mtDNA haplotypes. We first used the software program Cervus v3.0, which uses a categorical allocation approach and is the most commonly used method of parentage analysis (Jones et al. 2010). This approach is ideal when a pool of putative parents can be identified, as it provides a method to choose the single most likely parent. Cervus matched $92 \%$ of our 'ground truth' nests to the correct mother, with varying degrees of confidence. Three nests did not match the known mother: 1 was incorrectly assigned to a different female and 2 did not find a match. Additionally, we used Colony v2.0, which also uses maximum likelihood to assign both sibship and parentage relationships. This approach is useful when samples from all of the putative parents are unavailable. It first clusters the offspring into both paternal and maternal families, and then assigns candidate parents. When a suitable candidate parent is not identified, the program will reconstruct a parental genotype. With the Colony analysis, 4 nests were not assigned to the correct mother, 2 nests were incorrectly assigned to a different female, and 2 were not matched, so a maternal genotype was reconstructed. Interestingly, the 2 nests that were not matched using Colony were 2 of the same nests that were not correctly matched using Cervus, indicating a problem with the nests rather than the methods. These results are likely a consequence of genotyping error. In large studies characteristic of parentage analysis, both genotyping errors and mutations occur and result in apparent incompatibilities between true parents and their offspring, especially when highly variable markers are used (Jones et al. 2010). Both Cervus and Colony account for genotyping error. The rate of genotyping error is 1 of 2 key parameters in parentage analysis according to Jones et al. (2010). The best way to assess the genotyping error rate is through progeny arrays (Wang 2004). The second key parameter is the number of candidate parents, which can be difficult to determine. However, some analyses, such as parental reconstruction, are relatively unaffected by this parameter, since the statistical power is high and the data set robust. Colony proved to be a more useful analysis for our study, because we did not have a sample for all of the candidate mothers nor did we know how many candidate mothers were in the population. We did find that combining and evaluating the results from both programs provided a better estimate of the number of females nesting each year.

\section{Unknown nests}

Our new estimates based on genetic analysis are consistently higher than those previously derived from nest counts (Table 4), indicating that the nesting population is larger than previously thought. The number of clutches laid per female in Texas according to our results is generally lower than some estimates previously published for Kemp's ridleys at Rancho Nuevo, Mexico (NMFS et al. 2011). This difference might reflect different nesting patterns by Kemp's ridleys or monitoring efforts in the 2 regions. In Texas, nesting is more diffuse over a large stretch of coastline, some of which is only intermittently monitored, compared to Rancho Nuevo, where nesting in this larger population is more concentrated along a relatively shorter span of coastline that is intensively monitored. This would result in a greater likelihood of observing all nests laid by individual turtles. The uncertainty over the accuracy of published values for this parameter (number of nests per female) may also reflect different methodologies. The highest value ( 3.1 nests female ${ }^{-1}$ ) estimated by Rostal et al. (1997) was based on serum testosterone levels measured in nesters, and is much higher than those derived from CMR studies in Rancho Nuevo 
(1.8 to 2.5 nests female ${ }^{-1}$ ). The estimate made by Rostal et al. (1997) may represent what is theoretically possible as opposed to what is observed. Our estimate of the number of females should be considered conservative, since not all nests may be observed, and there are a few records of individuals nesting both in Mexico and in Texas. Additionally, 19 nests were not assigned, which suggests the existence of females that were not sampled or tagged, and not inferred by Colony. If the true value is closer to 1.8 nests female ${ }^{-1}$, then the predicted number of nests laid each year is close to the actual number observed, given the number of females we identified (Table 4). Further studies aimed at sampling nesters and nests across years will continue to improve our ability to identify minimum numbers of females 'observed' (from genetics) and enable quantification of population parameters (e.g. number of nests per female, inter-nesting interval) to improve population abundance estimation and demographic models in the future.

This study illustrates the utility of microsatellite genotypes in combination with the mtDNA sequence of nesting females and hatchlings salvaged from nests to census the number of females nesting annually in Texas. Systematic efforts to detect nesting along the Texas coast began at PAIS in 1986, and since then efforts have expanded at PAIS and elsewhere on the Texas coast (Shaver 2005). Despite the numerous challenges encountered, such as the hundreds of $\mathrm{km}$ to search, limited patrol resources, and the cryptic nesting characteristics of the species, the numbers of nests found in south Texas have increased since the mid-1990s (Shaver \& Rubio 2008). Our study supports these previous findings and provides a more accurate census of the nesting population than published studies which have been limited to nest counts.

\section{Conservation implications}

Kemp's ridleys face several threats in the Gulf of Mexico and along the US coast. Shrimp trawling has been identified as a causal factor for sea turtle strandings in Texas (Shaver 1998), since most of the stranded adult Kemp's ridleys from 1995 to 2003 were found during the time when the waters of the Texas coast were open to shrimp trawling (Shaver 2005). Adult mortality is a difficult demographic parameter to quantify in sea turtles in the absence of good CMR data (see Dutton et al. 2005). The genotype catalogue established in our study provides the basis for determining whether any stranded animals are parents of the nests sampled each year, including nests that were not assigned to any nesters subsequently observed and sampled. This would allow observed deaths to be accounted for in the nesting population, providing the means for more accurate threat and impact assessment in the future.

Acknowledgements. Work at PAIS was permitted under USFWS Permit TE840727-3 and Texas Parks and Wildlife Department Scientific Permit SPR-0190-122. Turtle handling and sampling was performed according to Institutional Animal Care Protocols NPS IACUC 2011-15. Funding was provided by the NPS and USGS. We thank the organizations that led efforts to detect the nesting turtles and nests, including: NOAA, Texas A\&M University-Galveston, USFWS, ARK, NPS, and Sea Turtle, Inc. T. Amos, B. Higgins, J. George, L. Guillen, C. Hughes, S. Keethan, A. Landry, Jr., J. Mays, A. McCracken, D. McKinney, E. Seney, C. Stinson, and others aided with detection of nests and collection of samples. A. Lanci, E. LaCasella, V. Pease, A. Konopacki, G. Serra-Valente, and R. LeRoux helped with laboratory work and sample processing. We thank R. LeRoux, B. Shamblin, B. Perrin, and 3 anonymous reviewers for suggestions that helped improve the manuscript. References to non-NOAA and NPS products and services are provided for information only and do not constitute endorsement or warranty, expressed or implied, by the US Government, as to their suitability, content, usefulness, functioning, completeness, or accuracy. Any use of trade, product, or firm names is for descriptive purposes only and does not imply endorsement by the US Government.

\section{LITERATURE CITED}

Abreu-Grobois A, Horrocks J, Formia A, Dutton P and others (2006) New mtDNA dloop primers which work for a variety of marine turtle species may increase the resolution capacity of mixed stock analysis. In: Frick M, Panagopoulou A, Rees AF, Williams K (eds) Book of abstracts from the 26th Annual Symp Sea Turtle Biol Conserv. International Sea Turtle Society, Athens, p 179

> Aggarwal RK, Velavan TP, Udaykumar D, Hendre PS, Shanker K, Choudhury BC, Singh L (2004) Development and characterization of novel microsatellite markers from the olive ridley sea turtle (Lepidochelys olivacea). Mol Ecol Notes 4:77-79

Allen ZC, Shah NJ, Grant A, Derand GD, Bell D (2010) Hawksbill turtle monitoring in Cousin Island Special Reserve, Seychelles: an eight-fold increase in annual nesting numbers. Endang Species Res 11:195-200

Balazs GH, Chaloupka M (2006) Recovery trend over 32 years at the Hawaiian green turtle rookery of French Frigate Shoals. Atoll Res Bull 543:147-158

Blouin M (2003) DNA-based methods for pedigree reconstruction and kinship analysis in natural populations. Trends Ecol Evol 18:503-511

Chaloupka M, Limpus CJ (2001) Trends in the abundance of sea turtles resident in southern Great Barrier Reef waters. Biol Conserv 102:235-249 
Cronin MA, Amstrup SC, Talbot SL, Sage GK, Amstrup KS (2009) Genetic variation, relatedness, and effective population size of polar bears (Ursus maritimus) in the southern Beaufort Sea, Alaska. J Hered 100:681-690

$>$ Dutton PH, Frey A (2009) Characterization of polymorphic microsatellite markers for the green turtle (Chelonia mydas). Mol Ecol Resour 9:354-356

Dutton PH, Sarti L, Márquez R, Squires D (2002) Sea turtle conservation across the shared marine border. In: Fernandez L, Carson RT (eds) Both sides of the border: transboundary environmental management issues facing Mexico and the United States. Kluwer Academic Publishers, Dordrecht, p 429-454

> Dutton DL, Dutton PH, Chaloupka M, Boulon RH (2005) Increase of a Caribbean leatherback turtle Dermochelys coriacea nesting population linked to long-term nest protection. Biol Conserv 126:186-194

FitzSimmons NN, Moritz C, Moore S (1995) Conservation and dynamics of microsatellite loci over 300 million years of marine turtle evolution. Mol Biol Evol 12:432-440

Fontaine C, Shaver D (2005) Head-starting Kemp's ridley sea turtle, Lepidochelys kempii, at the NMFS Galveston laboratory, 1978-1992: a review. Chelonian Conserv Biol 4:838-845

> Frey A, Dutton PH, Balazs GH (2013) Insights on the demography of cryptic nesting by green turtles (Chelonia mydas) in the main Hawaiian Islands from genetic relatedness analysis. J Exp Mar Biol Ecol 442:80-82

Herbinger CM, O'reilly PT, Verspoor E (2006) Unravelling first-generation pedigrees in wild endangered salmon populations using molecular genetic markers. Mol Ecol 15:2261-2275

> Jones OR, Wang J (2010) COLONY: a program for parentage and sibship inference from multilocus genotype data. Mol Ecol Resour 10:551-555

- Jones AG, Small CM, Paczolt KA, Ratterman NL (2010) A practical guide to methods of parentage analysis. Mol Ecol Resour 10:6-30

Kalinowski ST, Taper ML, Marshall TC (2007) Revising how the computer program CERVUS accommodates genotyping error increases success in paternity assignment. Mol Ecol 16:1099-1106

Kendall WL (2004) Coping with unobservable and mis-classified states in capture-recapture studies. Anim Biodivers Conserv 27:97-107

> Kendall WL, Bjorkland R (2001) Using open robust design models to estimate temporary emigration from capturerecapture data. Biometrics 57:1113-1122

Kumar RS, John S, Sivakumar K, Choudhury BC (2013) Egg laying duration in the olive ridley turtle (Lepidochelys olivacea) and its relevance for the estimation of mass nesting population size. Herpetol J 23:23-28

> Lee PLM (2008) Molecular ecology of marine turtles: new approaches and future directions. J Exp Mar Biol Ecol 356:25-42

- LeRoux RA, Dutton PH, Abreu-Grobois FA, Lagueux CJ and others (2012) Re-examination of population structure and phylogeography of hawksbill turtles in the Wider Caribbean using longer mtDNA sequences. J Hered 103: 806-820

Maniatis T, Fritsch E, Sambrook J (1982) Molecular cloning: a laboratory manual. Cold Spring Harbor Laboratory Press, Cold Spring Harbor, NY

NMFS (National Marine Fisheries Service) Southeast Fisheries Science Center (2008) Sea turtle research tech- niques manual. NOAA Tech Memo NMFS-SEFSC-579

NMFS (National Marine Fisheries Service), USFWS (US Fish and Wildlife Service), SEMARNAT (Secretaría del Medio Ambiente y Recursos Naturales) (2011) Bi-national recovery plan for the Kemp's ridley sea turtle (Lepidochelys kempii), 2nd rev. National Marine Fisheries Service, Silver Spring, MD

Peakall R, Smouse PE (2012) GenAlEx 6.5: genetic analysis in Excel. Population genetic software for teaching and research — an update. Bioinformatics 28:2537-2539

Raymond M, Rousset F (1995) An exact test for population differentiation. Evolution 49:1280-1283

> Richards PM, Epperly SP, Heppell SS, King RT and others (2011) Sea turtle population estimates incorporating uncertainty: a new approach applied to western North Atlantic loggerheads Caretta caretta. Endang Species Res 15:151-158

Rostal DC, Grumbles J, Byles R, Marquez-M R, Owens DW (1997) Nesting physiology of Kemp's ridley sea turtles, Lepidochelys kempii, at Rancho Nuevo, Tamaulipas, Mexico, with observations on population estimates. Chelonian Conserv Biol 2:538-547

> Rudnick JA, Katzner TE, Bragin EA, DeWoody JA (2007) A non-invasive genetic evaluation of population size, natal philopatry, and roosting behavior of non-breeding eastern imperial eagles (Aquila heliaca) in central Asia. Conserv Genet 9:667-676

Schroeder BA, Murphy SR (1999) Population surveys (ground and aerial) on nesting beaches. In: Eckert $\mathrm{K}$, Bjorndal K, Abreu-Grobois F, Donnelly M (eds) Research and management techniques for the conservation of sea turtles. IUCN/SSC Marine Turtle Specialist Group, Publication No. 4. www.sefsc.noaa.gov/turtles/ PR_Schroeder_Murphy_1999_MTSG.pdf

Sefc KM, Koblmüller S (2009) Assessing parent numbers from offspring genotypes: the importance of marker polymorphism. J Hered 100:197-205

> Shamblin BM, Faircloth BC, Dodd MG, Bagley DA and others (2008) Tetranucleotide markers from the loggerhead sea turtle (Caretta caretta) and their cross-amplification in other marine turtle species. Conserv Genet 10: $577-580$

Shaver DJ (1998) Sea turtle strandings along the Texas coast, 1980-94. In: Zimmerman, R (ed) Characteristics and causes of Texas marine strandings. NOAA Tech Rep NMFS 143:57-92

Shaver DJ (2005) Analysis of the Kemp's Ridley Imprinting and Headstart Project at Padre Island National Seashore, Texas, 1978-88, with subsequent nesting and stranding records on the Texas Coast. Chelonian Conserv Biol 4: 846-859

Shaver DJ, Caillouet CW (in press) Reintroduction of Kemp's ridley (Lepidochelys kempii) sea turtle to Padre Island National Seashore, Texas and its connection to headstarting. Herpetol Conserv Biol

Shaver DJ, Rubio C (2008) Post-nesting movement of wild and head-started Kemps ridley sea turtles Lepidochelys kempii in the Gulf of Mexico. Endang Species Res 4: 43-55

> Stewart KR, Dutton PH (2011) Paternal genotype reconstruction reveals multiple paternity and sex ratios in a breeding population of leatherback turtles (Dermochelys coriacea). Conserv Genet 12:1101-1113

Troëng S, Rankin E (2005) Long-term conservation efforts contribute to positive green turtle Chelonia mydas nest- 
ing trend at Tortuguero, Costa Rica. Biol Conserv 121: 111-116

Tucker A (2010) Nest site fidelity and clutch frequency of loggerhead turtles are better elucidated by satellite telemetry than by nocturnal tagging efforts: implications for stock estimation. J Exp Mar Biol Ecol 383:48-55

Van Oosterhout C, Hutchinson WF, Wills DPM, Shipley P (2004) Micro-Checker: software for identifying and correcting genotyping errors in microsatellite data. Mol Ecol Notes 4:535-538

Wang J (2004) Sibship reconstruction from genetic data with typing errors. Genetics 166:1963-1979

> Wang J, Santure AW (2009) Parentage and sibship inference from multilocus genotype data under polygamy. Genetics 181:1579-1594

Witherington B, Kubilis P, Brost B, Meylan AB (2009) Decreasing annual nest counts in a globally important loggerhead sea turtle population. Ecol Appl 19:30-54

Wright LI, Fuller WJ, Godley BJ, McGowen A, Tregenza T, Broderick A (2012) Reconstruction of paternal genotypes over multiple breeding seasons reveals male green turtles do not breed annually. Mol Ecol 21:3625-3635

Appendix

Table A1. Lepidochelys kempii. Mitochondrial DNA haplotypes, including variable sites and GenBank accession numbers

\begin{tabular}{|lcccccccccc|}
\hline \multirow{2}{*}{ Haplotype } & \multicolumn{8}{c}{ Position from start of dloop } & \multirow{2}{*}{ GenBank } \\
\cline { 2 - 8 } & 19 & 145 & 177 & 193 & 226 & 295 & 367 & 409 & accession no. \\
\hline Lk1.1 & T & T & C & A & A & G & C & G & KF385935 \\
Lk2.1 &. &. & A &. &. &. &. & A & KF385936 \\
Lk3.1 &. & C &. & G &. &. & T & A & KF385937 \\
Lk4.1 &. & C &. &. &. &. &. & A & KF385938 \\
Lk5.1 &. &. &. &. &. & A &. & A & KF385939 \\
Lk6.1 &. &. &. &. &. &. &. & A & KF385940 \\
Lk6.2 & G &. &. &. &. &. &. & A & KF385941 \\
Lk7.1 &. & C &. & G & G &. &. & A & KF385942 \\
\hline
\end{tabular}

Editorial responsibility: Matthew Godfrey,

Beaufort, North Carolina, USA
Submitted: April 16, 2013; Accepted: October 30, 2013 Proofs received from author(s): January 14, 2014 